УДК 91:504 (477)(075.8)

\title{
ВІДНОВЛЮВАЛЬНЕ ПРИРОДОКОРИСТУВАННЯ
}

\author{
Федір Кіптач \\ Львівський начіональний університет імені Івана Франка, \\ вул. П. Дорошенка, 41, 79000, м. Львів, Україна, \\ e-mail:kfgeoresurs@ukr.net
}

\begin{abstract}
Розкрито розуміння суспільством первинності екологічної парадигми свого розвитку. Висвітлено поняття та сутність відновлювального природокористування і головні засади раціонального використання земельних ресурсів. На підставі матеріалів грунтознавчих обстежень території Залісянської сільської ради Старосинявського р-ну Хмельницької обл. виокремлено два ландшафти: а) значно розчленованої височини лісостепу з чорноземами типовими малогумусними i чорноземами опідзоленими 3 фрагментами сірих лісових грунтів, у минулому з грабоводубовими лісами та різнотравно-злаковими степами, нині переважно розораними; б) середньо розчленованої височини лісостепу 3 чорноземами типовими глибокими малогумусними, у минулому з дубовими лісами і різнотравно-злаковими степами, нині переважно розораними. Розраховано частку грунтів, охоплених площинною і лінійною ерозією. Установлено природні та антропогенні чинники сприяння активному розвиткові ерозії грунтів у цьому регіоні. Обгрунтовано норми сприятливого співвідношення земельних угідь для двох лісостепових ландшафтів у межах території землекористування сільської ради з метою захисту грунтів від ерозії та поліпшення стану земель.
\end{abstract}

Ключові слова: відновлювальне природокористування, земельні ресурси, ландшафтні системи, земельні угіддя.

За сучасних умов землекористування сформована структура земельних угідь та їхнє просторове розміщення не повною мірою відповідають вимогам раціонального використання земель. Простежується недостатнє соціальне, економічне й екологічне обгрунтування розподілу їх за цільовим призначенням, особливо під час проведення земельної реформи та перерозподілу власності [4, с. 21]. Сільськогосподарська освоєність території перевищує екологічно обгрунтовані норми. Високий рівень розораності земель призвів до небаченого розвитку ерозії грунтів [6, с. 158].

Наслідки описаних несприятливих процесів і явищ закономірно спричинили погіршення стану земель лісостепу та пришвидшили загострення екологічних проблем у державі. 3 метою вирішення цих проблем, що виникли між суспільством і природою внаслідок господарської діяльності за умов прискореного руйнування нашого базису життя - ландшафтної сфери держави, суспільству необхідно оптимізувати землекористування за екологічними, соціальними й економічними параметрами.

Важливою умовою відродження природи (ренатуралізація) є розуміння суспільством первинності екологічної парадигми свого розвитку. Сутність парадигми охоплює не тільки збереження та охорону природних ландшафтних систем, відновлення біосферних циклів кругообігу речовини, енергії й інформації антропогенно модифікованих їхніх відмін та оптимізацію функціональних особливостей створених людиною штучних геотехносистем, а й здоровий спосіб життя, справедливу соціальну систему,

(C) Кіптач Ф., 2015 
філософію поваги і партнерства, турботу про прийдешнє покоління. Це шлях поступового переходу від суспільства споживання до суспільства майбутнього, яке задовольнятиме свої потреби мінімальним використанням природних ресурсів.

Первинність екологічної парадигми під час формування оптимізованої структури земельних угідь у межах землекористування сільських рад висвітлено у працях Ф. Кіптача [4-6], а також у працях В. Дьожкіна, В. Снакіна і Л. Попова, які присвячено відновлювальному природокористуванню $[1-3,7,8]$. Під відновлювальним природокористуванням науковці розуміють науково-практичний напрям природокористування, спрямований на охорону і відновлення біологічних природних ресурсів через організацію їхнього раціонального використання $[1-3,7,8]$. У нашому випадку цей науковопрактичний напрям природокористування спрямований на охорону і відновлення земельних ресурсів завдяки забезпеченню їхнього раціонального використання та відтворення, збереження екологічних, господарських і соціальних функцій земель, підвищення родючості грунтів і збереження ландшафтних систем держави. Раціональне використання земель ми розуміємо як наукове обгрунтування екотехнологій мінімізації використання земельних ресурсів i, навпаки, поліпшення їхніх корисних функцій та природних і набутих якостей для якнайповнішого забезпечення потреб суспільства за умови збереження саморегуляції та самовідновлення ландшафтних систем. Отже, раціональне використання земель грунтується на трьох головних засадах: а) мінімізації використання земельних ресурсів для реалізації еколого-виробничих програм і досягнення запланованих завдань; б) максимального використання корисних функцій земель і природних та набутих якостей з урахуванням наявних засобів і новітніх екотехнологій; в) найповнішого забезпечення потреб суспільства за умови збереження саморегуляції та самовідновлення ландшафтних систем. У нашому випадку цього частково можна досягти завдяки оптимізації розміщення земельних угідь 3 урахуванням ландшафтної структури території дослідної ділянки. Це перший крок забезпечення раціонального використання та відтворення земельних ресурсів.

Ми нарешті маємо усвідомити, що збереження якості не тільки земельних ресурсів, а й природного довкілля потрібно не лише людині як біологічному виду і соціальному організму, а й компонентам біоценозу (рослинам, тваринам, грибам і мікроорганізмам). Це особливо актуально за умов складної ландшафтної будови лісостепу, для якого характерна висока частка грунтів, охоплених площинною і лінійною ерозією. 3 метою захисту грунтів від ерозії та поліпшення стану земель необхідно для кожного ландшафту обгрунтувати норми сприятливого співвідношення земельних угідь.

Норми сприятливого співвідношення земельних угідь ми обгрунтували для території землекористування Залісянської сільської ради Старосинявського р-ну Хмельницької обл. на підставі власних матеріалів грунтознавчих обстежень 1996-1997 рр. (див. рисунок). Територія землекористування сільської ради розміщена в межах двох ландшафтів: а) значно розчленованої височини лісостепу з чорноземами типовими малогумусними і чорноземами опідзоленими з фрагментами сірих лісових грунтів, у минулому з грабово-дубовими лісами та різнотравно-злаковими степами, нині переважно розораними; б) середньо розчленованої височини лісостепу 3 чорноземами типовими глибокими малогумусними, у минулому з дубовими лісами і різнотравнозлаковими степами, нині переважно розораними.

Ландшафт значно розчленованої височини лісостепу з чорноземами типовими малогумусними і чорноземами опідзоленими з фрагментами сірих лісових грунтів, 
у минулому з грабово-дубовими лісами та різнотравно-злаковими степами, нині переважно розораними, займає правобережжя басейну р. Домаха і територіально межує 3 північною частиною землекористування Старосинявської сільської ради. Орографічні умови ділянки землекористування вирізняються глибоким вертикальним (40-50 м) i значним горизонтальним (0,76-1,00 км/км²) розчленуванням ярково-балковою мережею і низькою стійкістю до розвитку поверхневої та лінійної водної ерозії. Середньозважений показник крутості схилів ландшафтних систем становить 3,10. У морфологічній структурі ландшафту переважають схилові ландшафтні системи. Зокрема, ландшафтні системи слабковипуклих вододільних поверхонь пасом (0-1) займають усього 14,1\% від загальної площі землекористування сільської ради; схилів крутістю $1-2^{\circ}-16,3 \% ; 2-3-12,3 ; 3-5-19,2 ; 5-7-10,6 ; 7-10^{\circ}-27,5 \%$. Ландшафтні системи ерозійно небезпечних схилів крутістю понад $3-5^{\circ}$ займають 57,3 \% від загальної площі дослідної ділянки. Крім того, активному розвиткові ерозії грунтів у цьому регіоні значно сприяє достатня кількість опадів (540-580 мм/рік), висока інтенсивність злив (1,7-2,7 мм/хв), їхні великі добові максимуми (170-230 мм/добу) та значні запаси води в снігу (30-33 мм; останніми роками дещо менше). У структурі земельних угідь переважають екологічно дестабілізувальні угіддя - рілля та землі, виведені з сільськота лісогосподарського виробництва (господарські будівлі та помешкання, дороги, кар'єри, землі стороннього користування). Вони займають 95,0 \% (зокрема, рілля - 90,6 \%) від їхньої загальної площі. I навпаки, екологічно стабілізувальні угіддя (сади, пасовища, сіножаті, чагарники, лісосмуги, ліси, болота, води) становлять незначну частку - 5,0 \% від загальної площі дослідної ділянки. Унаслідок цього грунти, охоплені ерозією, дорівнюють 80,2% їхньої загальної площі. Ерозія грунтів зумовила зниження їхньої родючості та зменшення врожайності сільськогосподарських культур. Середньозважені втрати гумусу в грунтах орного горизонту (0-30 см) порівняно 3 повнопрофільними еталонами-аналогами $(3,2 \%)$ становлять $0,9 \%$.

Ландшафт середньо розчленованої височини лісостепу з чорноземами типовими глибокими малогумусними, у минулому з дубовими лісами і різнотравно-злаковими степами, нині переважно розораними, займає лівобережжя басейну р. Домаха і територіально межує з південною частиною землекористування Паплинецької сільської ради (див. рисунок). Орографічні умови ділянки землекористування вирізняються середньоглибоким вертикальним (20-30 м) і середнім горизонтальним $(0,51-0,75$ км/км²) розчленуванням, ярково-балковою мережею, а також середньою стійкістю до розвитку поверхневої та лінійної водної ерозії. Середньозважений показник крутості схилів ландшафтних систем становить $1,7^{\circ}$. У морфологічній структурі ландшафту вододільно-плакорні й схилові ландшафтні системи мають приблизно однакові частки відповідно, 44,7 і 55,3\%. Зокрема, ландшафтні системи слабковипуклих вододільних поверхонь $\left(0-1^{\circ}\right)$ пасом становлять $44,7 \%$ від загальної площі ландшафту в межах землекористування сільської ради; схилів крутістю $1-2^{\circ}-28,4 ; 2-3-12,9 ; 3-5-7,7$; $5-7-3,0 ; 7-10^{\circ}-3,3 \%$. Зазначимо, що ландшафтні системи ерозійно небезпечних схилів крутістю понад $3-5^{\circ}$ становлять $14,0 \%$. У структурі земельних угідь переважають екологічно дестабілізувальні угіддя - рілля та землі, виведені з сільсько- та лісогосподарського виробництва (господарські будівлі та помешкання, дороги, кар'єри, землі стороннього користування). Вони становлять 92,4 \% (зокрема, рілля - 85,8 \%) від їхньої загальної площі. І навпаки, екологічно стабілізувальні угіддя (сади, пасовища, сіножаті, чагарники, лісосмуги, ліси, болота, води) становлять незначний відсоток - 7,6. 


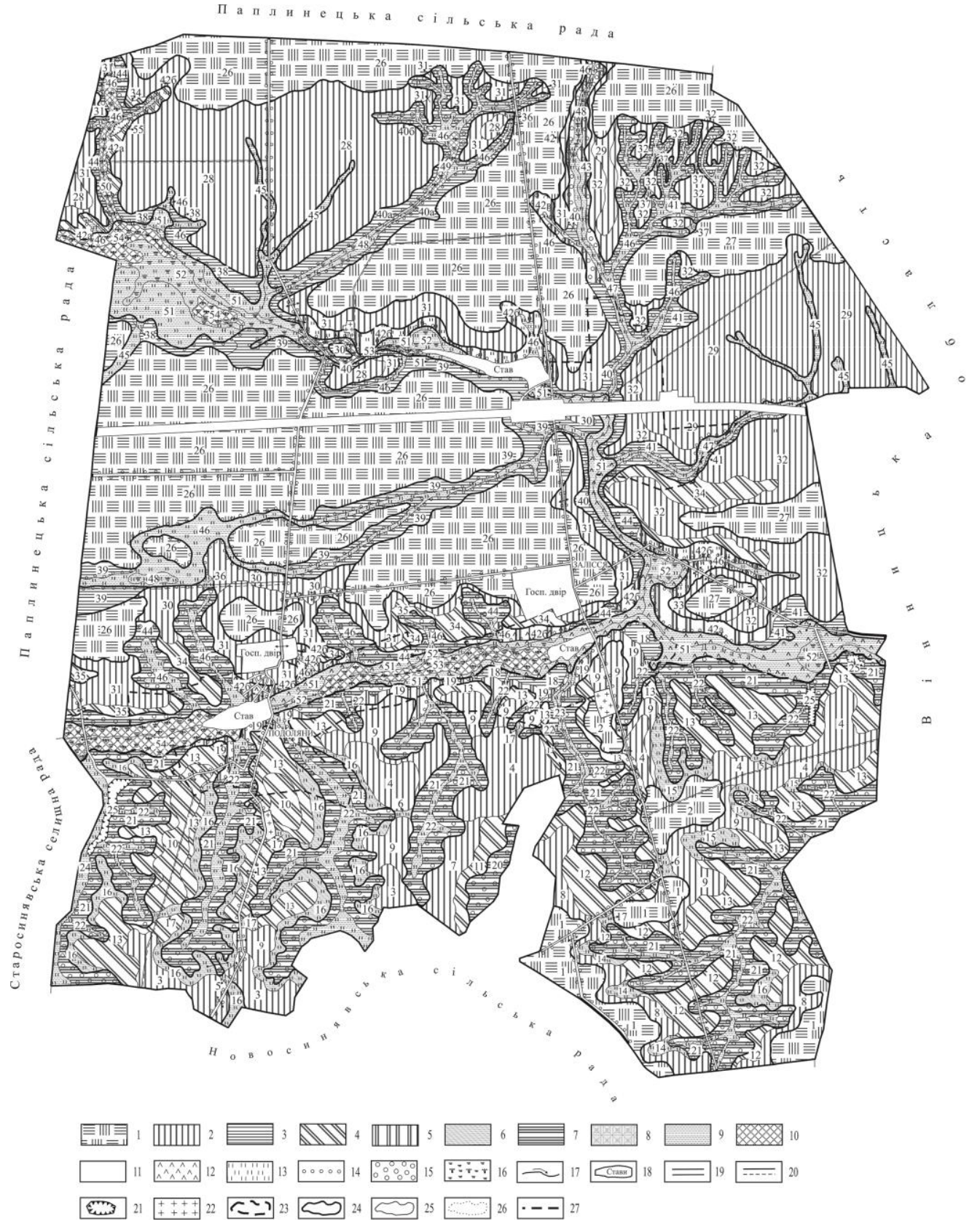

Оптимізована структура земельних угідь Залісянської сільської ради Старосинявського р-ну Хмельницької обл. 
1-10 - штрихові позначення земельних угідь за складом та цільовим призначенням у межах ландшафтних систем. Земельні угіддя: 11 - рілля; 12 - пасовища; 13 - сіножаті; 14 - лісосмуги; 15 - ліси; 16 - болота. Водні комплекси: 17 - річки; 18 - стави. Комунікації: 19 - залізниця, а також шосейні асфальтовані дороги; 20 - грунтові польові дороги. Кар'єрновідвальні ландмафтні системи: 21 - кар'єри видобутку піщано-глинистих і кам'яних (граніту) порід. Місия поховань: 22 - цвинтар. Межі морфологічних одинищь: 23 - ландшафтів; 24 - місцевостей; 25 - урочищ; 26 - підурочищ. Цифрами на картосхемі позначено ландшафтні системи - підурочища та урочища; 27 - межі села.

Ландшафт значно розчленованої височини лісостепу з чорноземами типовими малогумусними та чорноземами опідзоленими 3 фрагментами сірих лісових грунтів, у минулому з грабово-дубовими лісами і різнотравно-злаковими степами, нині переважно розораними.

Місцевість слабко випуклих вододільних поверхонь пасом і привододільних схилів з чорноземами типовими малогумусними та чорноземами опідзоленими 3 фрагментами сірих лісових грунтів, розорані. Урочища: 1 - слабко випуклі вододільні поверхні $\left(0-1^{\circ}\right)$ пасом 3 покривом лесів і чорноземів неглибоких малогумусних вилугуваних середньосуглинкових, під ріллю; 2 - слабко випуклі вододільні поверхні $\left(0-1^{\circ}\right)$ пасом 3 покривом лесів і чорноземів неглибоких малогумусних середньосуглинкових, під ріллю; 3 - привододільні слабкопологі схили $\left(1-2^{\circ}\right)$ пасом 3 покривом лесів і чорноземів неглибоких малогумусних вилугуваних слабкозмитих середньосуглинкових, під ріллю; 4 - привододільні слабкопологі схили $\left(1-2^{\circ}\right)$ пасом 3 покривом лесів і чорноземів неглибоких малогумусних середньосуглинкових, під ріллю.

Місцевість пологих і спадистих схилів пасом. Урочища: 5 - сідловини привододільних схилів пасом крутістю 2-3 3 покривом лесів і чорноземів неглибоких малогумусних вилугуваних слабкозмитих середньосуглинкових, під сіножаті з різнотравно-злаковою рослинністю; 6 - сідловини привододільних схилів пасом крутістю $2-3^{\circ} 3$ покривом лесів і чорноземів неглибоких малогумусних слабкозмитих середньосуглинкових, під сіножаті з різнотравно-злаковою рослинністю; 7 - слабкопологі схили $\left(2-3^{\circ}\right)$ пасом 3 покривом лесів і чорноземів опідзолених слабозмитих середньосуглинкових, під ріллю; 8 - слабкопологі схили $\left(2-3^{\circ}\right)$ пасом 3 покривом лесів і чорноземів неглибоких малогумусних вилугуваних слабкозмитих середньосуглинкових, під ріллю; 9 - слабкопологі схили $\left(2-3^{\circ}\right)$ пасом 3 покривом лесів і чорноземів неглибоких малогумусних слабкозмитих середньосуглинкових, під ріллю; 10 - слабкопологі схили $\left(2-3^{\circ}\right)$ пасом 3 покривом лесів і чорноземів неглибоких малогумусних середньозмитих середньосуглинкових, під ріллю; 11 - пологі схили $\left(3-5^{\circ}\right)$ пасом $з$ покривом лесів і чорноземів опідзолених середньозмитих середньосуглинкових, під ріллю; 12 - пологі схили $\left(3-5^{\circ}\right)$ пасом 3 покривом лесів і чорноземів неглибоких малогумусних вилугуваних середньозмитих середньосуглинкових, під ріллю; 13 - пологі схили $\left(3-5^{\circ}\right)$ пасом 3 покривом лесів і чорноземів неглибоких малогумусних середньозмитих середньосуглинкових, під ріллю; 14 - слабкоспадисті лійкоподібні схили $\left(5-7^{\circ}\right)$ пасом 3 покривом лесів і чорноземів неглибоких малогумусних вилугуваних середньозмитих середньосуглинкових, під сіножаті з різнотравно-злаковою рослинністю або заліснення; 15 - слабкоспадисті лійкоподібні схили (5-7 $)$ пасом 3 покривом лесів і чорноземів неглибоких малогумусних середньозмитих середньосуглинкових, під сіножаті 3 різнотравно-злаковою рослинністю або заліснення; 16 - слабкоспадисті схили $\left(5-7^{\circ}\right)$ пасом 3 покривом лесів і чорноземів типових малогумусних сильнозмитих середньосуглинкових, під сіножаті з різнотравно-злаковою рослинністю або заліснення; 17 - сідловини схилів пасом крутістю $3-5^{\circ} 3$ покривом лесів і чорноземів неглибоких малогумусних середньозмитих середньосуглинкових, під сіножаті з різнотравнозлаковою рослинністю.

Місцевість ярково-балкової мережі. Урочища: 18 - слабкопологі схили $\left(1-2^{\circ}\right)$ балок 3 покривом лесів і чорноземів неглибоких малогумусних слабозмитих середньосуглинкових, під ріллю; 19 - слабкоспадисті схили $\left(5-7^{\circ}\right)$ балок 3 покривом лесів і чорноземів неглибоких малогумусних середньозмитих середньосуглинкових, під ріллю; 20 - слабкоспадисті схили $\left(5-7^{\circ}\right)$ балок 3 покривом лесів і чорноземів опідзолених сильнозмитих середньосуглинкових, під грабово-дубові ліси; 21 - слабкоспадисті схили $\left(7-10^{\circ}\right)$ балок з покривом лесів і чорноземів типових малогумус- 
них сильнозмитих середньосуглинкових, під грабово-дубові ліси; 22 - днища верхів 'їв балок 3 покривом сучасних делювіальних відкладів і лучно-чорноземних намитих середньосуглинкових грунтів, під сіножаті 3 різнотравно-злаковою рослинністю; 23 - днища балок 3 покривом сучасних алювіально-делювіальних відкладів і лучних намитих середньосуглинкових грунтів, під сіножаті 3 різнотравно-злаковою рослинністю; 24 - днища балок 3 покривом сучасних алювіально-делювіальних відкладів і лучно-болотних середньосуглинкових грунтів, під сіножаті з осоково-різнотравною рослинністю.

Кар'єрно-відвальні ландшафтні системи: 25 - кар'єри видобутку піщано-глинистих порід. Після рекультивації - штучне заліснення або залуження.

Ландшафт середньорозчленованої височини лісостепу з чорноземами типовими глибокими малогумусними, у минулому з дубовими лісами і різнотравно-злаковими степами, нині переважно розораними.

Місцевість слабкохвилястих вододільних поверхонь пасом з чорноземами типовими глибокими малогумусними, розорані. Урочщща: 26 - слабкохвилясті вододільні поверхні $\left(0-1^{\circ}\right)$ пасом 3 покривом лесів і чорноземів глибоких малогумусних середньосуглинкових, під ріллю; 27 - слабкохвилясті вододільні поверхні $\left(0-1^{\circ}\right)$ пасом 3 покривом лесів і чорноземів глибоких малогумусних карбонатних середньосуглинкових, під ріллю.

Місцевість пологих і спадистих схилів пасом. Урочища: 28 - слабкопологі схили (1-2 $\left.{ }^{\circ}\right)$ пасом 3 покривом лесів і чорноземів глибоких малогумусних середньосуглинкових, під ріллю; 29 - слабкопологі схили $\left(1-2^{\circ}\right)$ пасом 3 покривом лесів і чорноземів глибоких малогумусних карбонатних середньосуглинкових, під ріллю; 30 - слабкопологі схили $\left(1-2^{\circ}\right)$ пасом 3 покривом лесів і чорноземів глибоких малогумусних слабкозмитих середньосуглинкових, під ріллю; 31 - слабкопологі схили $\left(2-3^{\circ}\right)$ пасом 3 покривом лесів і чорноземів глибоких малогумусних слабкозмитих середньосуглинкових, під ріллю; 32 - слабкопологі схили $\left(2-3^{\circ}\right)$ пасом 3 покривом лесів і чорноземів глибоких малогумусних карбонатних слабкозмитих середньосуглинкових, під ріллю; 33 - пологі схили $\left(3-5^{\circ}\right)$ пасом 3 покривом лесів і чорноземів глибоких малогумусних карбонатних слабкозмитих середньосуглинкових, під ріллю; 34 - пологі схили $\left(3-5^{\circ}\right)$ пасом 3 покривом лесів і чорноземів глибоких малогумусних середньозмитих середньосуглинкових, під ріллю; 35 - слабкоспадисті схили $\left(5-7^{\circ}\right)$ пасом 3 покривом лесів і чорноземів глибоких малогумусних середньозмитих середньосуглинкових, під ріллю; 36 - сідловини схилів пасом крутістю $2-3^{\circ}$ з покривом лесів i чорноземів глибоких малогумусних слабкозмитих середньосуглинкових, під сіножаті з різнотравно-злаковою рослинністю; 37 - сідловини схилів пасом крутістю $3-5^{\circ} 3$ покривом лесів і чорноземів глибоких малогумусних карбонатних слабкозмитих середньосуглинкових, під сіножаті з різнотравно-злаковою рослинністю.

Місцевість ярково-балкової мережі. Урочища: 38 - слабкопологі схили (1-2) балок 3 покривом лесів і чорноземів глибоких малогумусних середньосуглинкових, під ріллю; 39 - слабкопологі схили $\left(2-3^{\circ}\right)$ балок 3 покривом лесів і чорноземів глибоких малогумусних слабкозмитих середньосуглинкових, під ріллю; 40 - пологі схили $\left(3-5^{\circ}\right)$ балок 3 покривом лесів і чорноземів глибоких малогумусних слабкозмитих середньосуглинкових. Підурочщщза: 40a - під ріллю; $40 б$ - під сіножаті з різнотравно-злаковою рослинністю; 41 - пологі схили (3-5) балок 3 покривом лесів і чорноземів глибоких малогумусних карбонатних слабкозмитих середньосуглинкових. Підурочища: 41a - під ріллю; 416 - під грабово-дубові ліси; 42 - слабкоспадисті схили $\left(5-7^{\circ}\right)$ балок $з$ покривом лесів і чорноземів глибоких малогумусних середньозмитих середньосуглинкових. Підурочища: 42a - під ріллю; 426 - під кормові угіддя з різнотравно-злаковою рослинністю (сіножаті, пасовища); 42в - під грабово-дубові ліси; 43 - слабкоспадисті схили $\left(7-10^{\circ}\right)$ балок 3 покривом лесів і чорноземів глибоких малогумусних середньозмитих середньосуглинкових, під грабово-дубові ліси; 44 - слабкоспадисті схили (7-10) балок з покривом лесів і чорноземів типових малогумусних сильнозмитих середньосуглинкових. Підурочища: 44a - під кормові угіддя з різнотравно-злаковою рослинністю (сіножаті, пасовища); 44б - під грабово-дубові ліси; 45 - слабковиражені видолинки стоку на слабкопологих схилах $\left(1-2^{\circ}\right)$ пасом 3 покривом сучасних делювіальних відкладів і лучно-чорноземних намитих середньосуглинкових грунтів, під сіножаті з різнотравно-злаковою рослинністю; 46 - днища балок 3 покривом сучасних 
делювіальних відкладів і лучно-чорноземних намитих середньосуглинкових грунтів, під сіножаті 3 різнотравно-злаковою рослинністю; 47 - днища балок 3 покривом сучасних алювіальноделювіальних відкладів і лучних намитих середньосуглинкових грунтів, під сіножаті з різнотравно-злаковою рослинністю; 48 - днища балок 3 покривом сучасних алювіально-делювіальних відкладів і лучно-болотних середньосуглинкових грунтів, під сіножаті з осоково-різнотравною рослинністю; 49 - днища балок 3 покривом сучасних алювіально-делювіальних відкладів і мулувато-болотних грунтів, під болото з очеретяно-осоковою рослинністю; 50 - днища балок 3 покривом органогенних відкладів і торфовищ низинних неглибоких сильно розкладених, під болото з очеретяно-осоковою рослинністю.

Місцевість заплави річки Домахи. Урочищза: 51 - заплава середнього рівня 3 покривом алювіально-делювіальних відкладів і лучних намитих середньосуглинкових грунтів, під кормові угіддя 3 різнотравно-злаковою рослинністю (сіножаті, пасовища); 52 - заплава низького рівня 3 покривом алювіально-делювіальних відкладів і лучно-болотних середньосуглинкових грунтів, під сіножаті 3 осоково-різнотравною рослинністю; 53 - заплава низького рівня 3 покривом алювіально-делювіальних відкладів і мулувато-болотних грунтів, під болото 3 очеретяноосоковою рослинністю; 54 - заплава низького рівня 3 покривом органогенних відкладів i торфовищ низинних неглибоких сильно розкладених, під болото 3 очеретяно-осоковою рослинністю.

Комунікації - залізниця, а також шосейні асфальтовані та грунтові польові дороги. Обов'язкові придорожні стрічкові лісові або чагарникові насадження.

Унаслідок описаних чинників грунти в межах ландшафту середньо розчленованої височини лісостепу з чорноземами типовими глибокими малогумусними, у минулому 3 дубовими лісами і різнотравно-злаковими степами, нині переважно розораними, охоплені ерозією, становлять усього 29,4 \% від його загальної площі. Ерозія грунтів зумовила зниження їхньої родючості та зменшення врожайності сільськогосподарських культур. Середньозважені втрати гумусу в грунтах орного горизонту (0-30 см) порівняно 3 повнопрофільними еталонами-аналогами $(3,9 \%)$ становлять $0,2 \%$.

Розміщення земельних угідь за складом та цільовим призначенням, а також агросівозміни в їхніх межах виокремлено штрихуванням: 1 - польові зернопаропросапні сівозміни і вирощування всіх сільськогосподарських культур цієї зони за інтенсивними технологіями; 2, 3 - польові зернопаропросапні сівозміни і вирощування всіх сільськогосподарських культур цієї зони за інтенсивними технологіями за умови обробітку грунту, сівби та догляду за посівами в напрямі горизонталей. Обов'язкові прирічкові водоохоронні та грунтозахисні стрічкові лісові й чагарникові насадження. За потреби кормові угіддя - пасовища і сіножаті; 4, 5 - польові зерно-трав'яні або трав'яно-зернові грунтозахисні сівозміни з повним вилученням просапних культур. Обов'язкові прирічкові водоохоронні та грунтозахисні стрічкові лісові насадження і кормові угіддя; 6 - штучне або природне залуження. Спочатку сінокісне призначення, а в майбутньому, через п'ять-сім років, - пасовищне. За потреби заліснення; 7 - малопридатні для кормових угідь сильно розчленовані розмивинами спадисті схили призначені під заліснення. За потреби штучне або природне залуження. Спочатку сінокісне призначення, а в майбутньому, через сім-десять років, - пасовищне; 8, 9 - природне залуження кормові угіддя (сіножаті, пасовища). Спочатку сінокісне призначення, а в майбутньому, через сім-десять років, - пасовищне; 10 - болота. Після виробітку кар'єрів обов'язкове штучне заліснення або залуження, а навколо доріг - придорожні стрічкові лісові або чагарникові насадження. 
Отже, оптимізація структури земельних угідь з урахуванням складної ландшафтної будови дослідної ділянки засвідчує, що в межах ландшафтів:

а) значно розчленованої височини лісостепу з чорноземами типовими малогумусними і чорноземами опідзоленими 3 фрагментами сірих лісових грунтів орні землі повинні займати не більше 46,9 \% від загальної площі ландшафту в межах дослідної ділянки. Зокрема: 6,1 \% рекомендовано використовувати під польові зернопаропросапні сівозміни і вирощування всіх сільськогосподарських культур цієї зони за інтенсивними технологіями; 22,4% - під польові зернопаропросапні сівозміни і вирощування всіх сільськогосподарських культур цієї зони за інтенсивними технологіями за умови обробітку грунту, сівби та догляду за посівами у напрямі горизонталей; 18,4 \% - під польові зернотрав'яні або трав'яно-зернові грунтозахисні сівозміни з повним вилученням просапних культур; 49,3 \% від загальної площі дослідної ділянки повинні займати багаторічні насадження $(0,5 \%)$, пасовища $(2,2)$, сіножаті $(19,2)$, чагарники і лісосмуги $(0,02)$, ліси $(25,4)$, болота $(1,38)$, води $(0,6 \%)$. Решту $3,8 \%$ займають господарські будівлі та помешкання $(0,7$ \%), дороги $(1,6)$, кар'єри $(0,6)$, землі стороннього користування $(0,9 \%)$;

б) середньо розчленованої височини лісостепу з чорноземами типовими глибокими малогумусними орні землі повинні займати не більше 61,0\% від загальної площі ландшафту в межах дослідної ділянки. Зокрема: 33,8 \% рекомендовано використовувати під польові зернопаропросапні сівозміни і вирощування всіх сільськогосподарських культур цієї зони за інтенсивними технологіями; 21,9 \% - під польові зернопаропросапні сівозміни і вирощування всіх сільськогосподарських культур цієї зони за інтенсивними технологіями за умови обробітку грунту, сівби та догляду за посівами у напрямі горизонталей; 5,3\% - під польові зерно-трав'яні або трав'яно-зернові грунтозахисні сівозміни 3 повним вилученням просапних культур; 33,27 \% від загальної площі дослідної ділянки повинні займати багаторічні насадження $(1,6 \%)$, пасовища $(2,4)$, сіножаті $(19,3)$, чагарники і лісосмуги $(0,5)$, ліси $(7,87)$, болота $(0,8)$, води $(0,8 \%)$. Решту $5,73 \%$ займають господарські будівлі та помешкання $(0,7 \%)$, дороги $(1,5)$, кар'єри $(0,03)$, землі стороннього користування $(3,5 \%)$.

Отримані результати дали змогу обгрунтувати норми сприятливого співвідношення земельних угідь для території землекористування Залісянської сільської ради. Це перший крок до створення сталих ландшафтно-екологічних систем за принципом відновлення земельних ресурсів і посилення процесів їхньої стійкості та саморегуляції завдяки розширенню площі екологічно стабілізувальних земельних угідь малопродуктивних земель.

У майбутньому з державного бюджету необхідно виділяти кошти суб’єктам права власності на землю для переобстеження грунтів 3 використанням нових технологій i технічного забезпечення. На підставі отриманих результатів потрібно оптимізувати структуру земельних угідь з урахуванням ландшафтної будови території землекористувань. Це забезпечить повноту інформації для укладання державного земельного (грунтового, ландшафтного) кадастру і проведення економічної оцінки земель.

\section{СПИСОК ВИКОРИСТАНОЇ ЛІТЕРАТУРИ}

1. Дёжкин В. В. Основы биологического природопользования : учеб. пособие / В. В. Дёжкин, Л. В. Попова. - М. : Модус-К : Этерна, 2005. - 320 с. 
2. Дёжкин B. B. Экология природовозрождения (заметки о восстановительном природопользовании) / В. В. Дёжкин, В. В. Снакин, Л. В. Попова // Использование и охрана природных ресурсов в России. - 2007. - № 4. - С. 3-11.

3. Дёжкин В. В. Экология возрождения природы / В. В. Дёжкин, В. В. Снакин, Л. В. Попова // Охота и охотничье хозяйство. - 2008. - № 2. - С. 8-11.

4. Кіптач $\Phi$. Метризація екологічного стану земельних ресурсів лісостепових ландшафтів : монографія / Ф. Кіптач, С. Кукурудза. - Львів : Видавничий центр ЛНУ імені Івана Франка, 2002. - 119 с.

5. Кіптач Ф. Депресивні регіони України : екологічна компонента: монографія / Ф. Кіптач. - Львів : Видавничий центр ЛНУ імені Івана Франка, 2008. - 288 с.

6. Кіптач Ф. Землі України: категорії, право власності, стан використання, охорона : навч. посібник / Ф. Кіптач. - Львів : Видавничий центр ЛНУ імені Івана Франка, 2010. $-240 \mathrm{c}$.

7. Снакин В. В. Экология природовозрождения и рациональное природопользование / В. В. Снакин, В. В. Дёжкин // Вестник Росприроднадзора. - 2010. - № 1. - С. 16-25.

8. Снакин В. В. Возобновление ландшафтов в рамках восстановительного природопользования / В. В. Снакин, А. А. Присяжная // Рекультивация сложных техноэкосистем в новом тысячелетии: ноосферный аспект: материалы междунар. науч.практ. конф. - Днепропетровск : ДДАУ, 2012. - С. 349-352.

\section{REFERENCES}

1. Djozhkin, V. V., \& Popova, L. V. (2005). Osnovy biologicheskogo prirodopol'zovanija. Moskva: Modus-K: Jeterna, 320 pp. (in Russian).

2. Djozhkin, V. V., Snakin, V. V., \& Popova, L. V. (2007). Ekologija prirodovozrozhdenija (zametki o vosstanovitel'nom prirodopol'zovanii). Ispol'zovanie $i$ ohrana prirodnyh resursov v Rossii, 4, 3-11 (in Russian).

3. Djozhkin, V. V., Snakin, V. V., \& Popova, L. V. (2008). Jekologija vozrozhdenija prirody. Ohota i ohotnich'e hozjajstvo, 2, 8-11 (in Russian).

4. Kiptach, F., \& Kukurudza, S. (2002). Metryzatsiia ekolohichnoho stanu zemelnykh resursiv lisostepovykh landshaftiv. Lviv: Vydavnychyi tsentr LNU imeni Ivana Franka, 119 pp. (in Ukrainian).

5. Kiptach, F. (2008). Depresyvni rehiony Ukrainy: ekolohichna komponenta. Lviv: Vydavnychyi tsentr LNU imeni Ivana Franka, 288 pp. (in Ukrainian).

6. Kiptach, F. (2010). Zemli Ukrainy: katehorii, pravo vlasnosti, stan vykorystannia, okhorona. Lviv: Vydavnychyi tsentr LNU imeni Ivana Franka, 240 pp. (in Ukrainian).

7. Snakin, V. V., \& Djozhkin, V. V. (2010). Ekologija prirodovozrozhdenija i racional'noe prirodopol'zovanie. Vestnik Rosprirodnadzora, 1, 16-25 (in Russian).

8. Snakin, V. V., \& Prisjazhnaja, A. A. (2012). Vozobnovlenie landshaftov v ramkah vosstanovitel'nogo prirodopol'zovanija. Proceedings from: Rekul'tivacija slozhnyh tehnojekosistem $v$ novom tysjacheletii: noosfernyj aspekt. Dnepropetrovsk: DDAU, 349-352 (in Russian). 


\title{
RENEWABLE USING OF NATURAL RESOURCES
}

\section{Fedir Kiptach}

Ivan Franko National University of Lviv,

\author{
P. Doroshenko Str., 41, UA - 79000 Lviv, Ukraine
}

e-mail:kfgeoresurs@ukr.net

The primacy of public understanding of ecological paradigm of development was revealed. The concept and essence of renewable using of natural resources and the main principles of management of land resources were illustrated. Two landscapes were singled out based on materials of soil studies of the territory of the village council Zalissya in Starosinyavskiy district, Khmelnytskyi region. Among them: a) much-dissected upland of a forest-steppe with black soils, humus, typical and ashed, with fragments of grey forest soils, in the past with hornbeam-oak forests and herb-grass steppe, now largely ploughed; b) mediumdissected upland of a forest-steppe with black soils, low content of humus, typical, deep, in the past with oak forests and herb-grass steppe, now largely ploughed. Fraction of soils covered flatness and linear erosion was calculated. Natural and anthropogenic factors promoting the active development of erosion in this region were identified. Norms of favourable correlation of lands for two forest-steppe landscapes within the territory of land use of the village council Zalissya with the purpose of protecting the soils from erosion and improvement of the land state were grounded.

Key words: renewable using of natural resources, land resources, landscapes systems, lands. 